\title{
Kaj je zdrav gozd?
}

\section{Nikica OGRIS*}

Zdrav gozd je kompleksen pojem, za katerega obstaja mnogo definicij. Gozd je ekosistem, zato je prav, da obravnavani pojem definiramo kot zdrav gozdni ekosistem. V preteklosti je definicija zdravja ekosistema vključevala več konceptov (Costanza in Mageau, 1999; Jørgensen in sod., 2005): homeostazo, odsotnost bolezni, pestrost ali kompleksnost, stabilnost ali odpornost, vitalnost ali težnjo po rasti in ravnotežje med komponentami sistema.

Čeprav pri premišljevanju o zdravju gozda lahko upoštevamo vse ali vsaj večino navedenih pogledov, to velikokrat ni dovolj za izpolnjevanje pogojev zdravega ekosistema. Vsi našteti pogledi niso dovolj splošni in ne vključujejo pogleda trajnosti. Zdrav ekosistem je tisti, ki je trajen (slika 1), t. j. ima sposobnost vzdrževati zgradbo (organizacijo) in funkcijo (vitalnost) skozi čas kljub stresnim dejavnikom (odpornost) (Costanza in Mageau, 1999; Brown in Ulgiati, 2005).

Pri definiciji zdravega gozdnega ekosistema, je treba upoštevati, da motnja (stresni dejavnik) nikakor ni tujek v gozdnem ekosistemu: je gibalo njegovega sukcesijskega razvoja in dinamičnosti njegovega ravnotežja (Anko, 1993). Stresni dejavniki v gozdu so pomembni tudi zato, ker zmanjšujejo prilagodljivost gozdnega ekosistema po gozdnogospodarskih ukrepih, katerih cilj je oblikovanje mnogo namenskega gozda.

Kako vemo, kdaj je gozd zdrav? Zdravje gozda bi lahko ocenilo več izvedencev, in sicer vsak iz svojega pogleda. Skupna ocena bi morda pokazala, koliko je gozd zdrav. Lahko pa zdravje gozda izmerimo. Organizacijo (zgradbo), vitalnost in odpornost gozdnega ekosistema je mogoče boljše ali slabše meriti z različnimi kazalci. Tako je, npr., kazalec za vitalnost metabolizem, za organizacijo vrstna pestrost in za odpornost čas okrevanja.

V Sloveniji se z zdravjem gozda neposredno in največ ukvarja varstvo gozdov, v okviru tega pa Poročevalska, prognostično- diagnostična služba za gozdove, ki je del javne gozdarske službe (Jurc, 2006).

V varstvu gozdov so se uveljavili trije izrazi: bolezen, škodljivec in abiotska poškodba kot glavni vzroki za krhanje zdravja gozda. Ob tem navajamo njihove definicije.

- Bolezen je vsaka motnja metabolizma (presnove) in anatomsko-histološke strukture, izzvana zaradi biotskih ali abiotskih dejavnikov, ki slabijo življenjsko moč rastline, če motnja negativno vpliva na idealno ali gospodarsko vrednost (uporabnost) rastline (Maček, 2008). V vsakodnevni in najpogostejši rabi v gozdarstvu besedo bolezen uporabljamo $\mathrm{v}$ tistih primerih, ko jo povzroča zajedavska gliva (redko bakterija ali virus).

- Škodljivec ali škodljivi organizem je katera koli vrsta, sev ali biotip rastline, živali ali patogenega povzročitelja, ki škoduje rastlinam ali rastlinskim proizvodom (FAO glossary ..., 1990). V slovenščini uporab- ljamo besedo škodljivec takrat, ko poškodbe povzroča žival (najpogosteje žuželka) (Slovar slovenskega knjižnega jezika, 2000).

- Abiotska poškodba je poškodba zaradi škodljivega neživega dejavnika. Najpogostejši škodljivi abiotski dejavniki, ki delujejo na gozd, so: žled, sneg, veter, onesnažen zrak, požar, usad in plaz.

Vedno več je dokazov, da je zdrav ekosistem tisti, ki je bogat s paraziti (Hudson in sod., 2006). Trditev je v nasprotju z zahtevami za zdrav ekosistem, ki sta jih postavila Costanza in Mageau (1999), t. j., da v zdravem ekosistemu ni bolezni, kar povzroča paradoks $\mathrm{v}$ obravnavni definiciji. To je na videz sporna trditev, saj paraziti lahko pomembno vplivajo na zdravje posameznega drevesa. Vendar je njihov vpliv lahko veliko pomembnejši dolgoročno, $\mathrm{v}$ evolucijskem razvoju: oblikujejo populacijsko dinamiko svojih gostiteljev, spremenijo interspecifično tekmovanje, vplivajo na pretok energije $\mathrm{v}$ ekosistemu in so pomembni gonilniki biotske pestrosti. Zato vplivajo na vrsto ekosistemskih funkcij, njihov vpliv pa je zelo velik na zgradbo nekaterih prehrambnih verig. Paraziti lahko vplivajo na dolžino prehranjevalnih verig in na število povezav med različnimi trofičnimi ravnmi. Če paraziti prispevajo k podaljševanju prehranjevalnih verig, ki so sestavljene iz številnih vrst in imajo mnoge povezave, posledično lahko prispevajo $\mathrm{k}$ večji stabilnosti zgradbe združbe in prehranjevalnih verig. Zaradi vsega naštetega so paraziti lahko dober pokazatelj zdravja ekosistema in dolgoročno celo prispevajo k zdravju gozda.

\section{Viri}

Anko B. 1993. Vpliv motenj na gozdni ekosistem in na gospodarjenje z njim. Zbornik gozdarstva in lesarstva, 42: 85-109

Brown M.T., Ulgiati S. 2005. Emergy, transformity, and ecosystem health. V: Handook of ecological indicators for assessment of ecosystem health. Jørgensen S.E., Costanza R., Xu F.-L. (ur.). CRC Press: 333-352

Costanza R., Mageau M. 1999. What is a healthy ecosystem? Aquatic Ecology, 33, 1: 105-115

FAO Glossary of phytosanitary terms. FAO Plant Protection Bulletin, 38, 1: 5-23

Hudson P.J., Dobson A.P., Lafferty K.D. 2006. Is a healthy ecosystem one that is rich in parasites? Trends in Ecology \& Evolution, 21, 7: 381-385

Jørgensen S.E., Xu F.-L., Salas F., Marques J.C. 2005. Application of indicators for the assessment of ecosystem health. V: Handook of ecological indicators for assessment of ecosystem health Jørgensen S.E., Costanza R., Xu F.-L. (ur.). CRC Press: 5-66

Jurc D. 2006. Mesto poročevalske, diagnostične in prognostične službe za gozdove v sistemu varstva rastlin Slovenije. V: Monitoring gospodarjenja z gozdom in gozdnato krajino. Hladnik D. (ur.). Ljubljana, Univerza v Ljubljani, Biotehniška fakulteta, Oddelek za gozdarstvo in obnovljive gozdne vire: $167-180$

Maček J. 2008. Gozdna fitopatologija. Ljubljana, Zavod za gozdove Slovenije, Zveza gozdarskih društev Slovenije - Gozdarska založba: 448 str.

*Gozdarski inštitut Slovenije, Večna pot 2, 1000 Ljubljana nikica.ogris@gozdis.si 


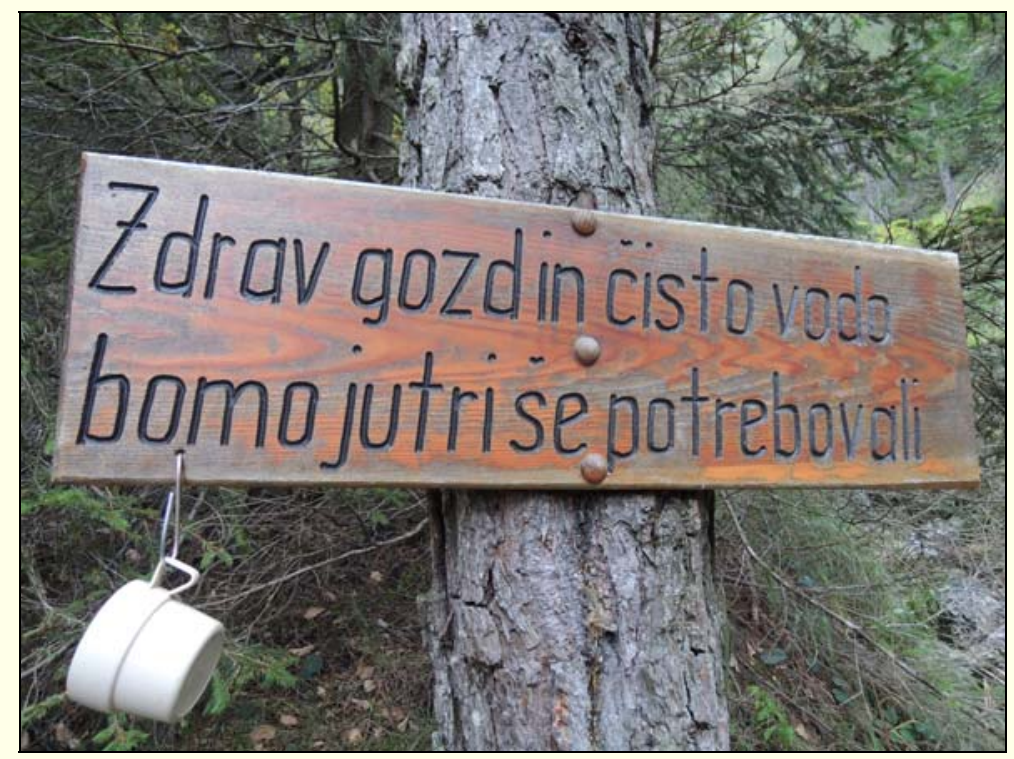

Slika 1: Tabla na poti na Veliko Poljano iz Povelj opozarja na trajnostni pomen zdravega gozda in čiste vode (Foto: Nikica Ogris) 